\title{
História e evolução da Psicologia Genética: um estudo do desenvolvimento das pesquisas com crianças
}

Os estudos de Jean Piaget e colaboradores tornaram-se, muito possivelmente, quando o tema é a inteligência, a grande referência no campo da psicologia contemporânea. Contudo, os estudos piagetianos estão mais ligados à dimensão epistemológica, valendo-se da pesquisa psicológica para a compreensão dos processos de construção do conhecimento. Alguém que leia os estudos de Piaget de uma maneira isolada, ou o próprio conjunto de pesquisas da Epistemologia Genética, pode ter, em uma primeira impressão, a noção de que a psicologia é apenas um trampolim para os estudos sobre o conhecimento. Ledo engano. Ao redor de Piaget organiza-se o fecundo campo de trabalho que se costuma chamar Escola de Genebra. A Epistemologia Genética não vive isolada; tem como parceira indissociável, entre outras, a Psicologia Genética. Esta última, mais preocupada com os processos particulares de um sujeito psicológico, do que com as grandes categorias do pensamento.

$\mathrm{O}$ artigo que ora apresento traz o caminho que a Psicologia Genética percorreu na sua própria construção, bem como a relação indelével que apresenta com a dimensão epistemológica. Bärbel Inhelder firmou-se como principal colaboradora de Piaget. Ela divide a coautoria de diversas obras que abordam aspectos centrais do pensamento que, convencionalmente, se chamou de piagetiano. Contudo, ela tem uma produção acadêmica própria, mais direcionada a aspectos psicológicos e funcionalistas. A genialidade e originalidade de suas pesquisas nos permitem atribuir a ela um papel essencial e indispensável na construção da teoria, com ênfase para a Psicologia Genética. Inhelder soube manter uma colaboração estreita com Piaget, bem como dele distanciar-se para empreender estudos de interesse próprio. Embora desconhecida do grande público, podese falar de uma psicologia inhelderiana, tamanha a dimensão de sua contribuição aos estudos do sujeito psicológico.

Para fazer o resgate do trabalho de Bärbel Inhelder e o percurso trilhado pela Psicologia Genética, as autoras do texto escolhem a construção do método de investigação como parâmetro para acompanhar as evoluções e necessidades de adequação que a abordagem sofreu. $O$ chamado método clínico não se apresentou de uma maneira acabada, refletindo o próprio contexto no qual está inserido. Ele vai se construindo e se adaptando à medida que as elaborações teóricas nos campos epistemológico e psicológico vão se organizando.

As autoras do artigo destacam-se pela relevância e repercussão de seus trabalhos. A Dra. Silvia ParratDayan é pesquisadora junto aos Archives Jean Piaget, da Universidade de Genebra. É organizadora da obra Sobre a Pedagogia: textos inéditos, de grande repercussão na comunidade acadêmica brasileira, na qual apresenta ao leitor vários textos de autoria do próprio Piaget, que eram de difícil acesso ao grande público. A Dra. Luísa Morgado é Professora Catedrática de Psicologia da Universidade de Coimbra, em Portugual. Publicou Homengagem a Bärbel Inhelder, dentre outras obras.

O texto que se segue é de vital importância para os que querem compreender o contexto existente em Genebra durante a condução das pesquisas de Piaget e Inhelder, principalmente, no que tange a aspectos metodológicos. É de suma relevância para compreender uma dimensão psicológica dentro da teoria, atribuindo a Bärbel Inhelder uma relevância que muitas vezes é esquecida ou tratada de maneira negligenciada.

Por fim, este primoroso artigo trata-se de um documento histórico que resgata parte do próprio percurso que a Psicologia, enquanto ciência percorreu ao longo do Século $X X$, sendo de indispensável leitura para os estudiosos que querem compreender, com maior profundidade, as idéias que hoje são discutidas nos campos da Epistemologia e Psicologia Genéticas.

João Alberto da Silva Universidade Federal de Pelotas 